\title{
IAMJ
}

INTERNATIONAL

AYURVEDIC

MEDICAL JOURNAL

\section{AYURVEDA PERSPECTIVE OF UNDERNUTRITION IN CHILDREN \& ITS MANAGEMENT: A SYSTEMIC REVIEW}

\author{
$\underline{\text { Warole Ruchita Bhimrao }}^{1}$, $\underline{\text { Ramteke Rachana }}^{2}$, $\underline{\text { Thokal Devyani }}^{3}$, $\underline{\text { Nagre Narayan }}^{4}$ \\ ${ }^{1}$ P.G. Scholar, ${ }^{2}$ Associate Professor, ${ }^{3}$ H.O.D, Professor, ${ }^{4}$ P.G. Scholar \\ Dept of Kaumarbhritya, Shree Ayurved Mahavidyalaya, Nagpur, Maharashtra, India
}

Corresponding Author: ruchitabwarole@gmail.com

https://doi.org/10.46607/iamj1209032021

(Published online: March 2021)

Open Access

(C) International Ayurvedic Medical Journal, India 2021

Article Received: 09/02/2021 - Peer Reviewed: 11/02/2021 - Accepted for Publication: 17/02/2021

\section{(A) Check for updates}

\section{ABSTRACT}

Karshya (Underweight) is one of the common problems in Indian preschool children \& 43\% Indian preschool children are underweight. One of important factor for Karshya is Hina Matra Ahara (inadequate quantity of food). About 75-80\% of Hospitalized children suffer from some degree or type of malnutrition. Lots of attempt have been made to minimize this at National level. Mid-day meal program to school going children alone will not be sufficient.so Aim of study is to review on management of Karshya. Material and Methods - Literary review was conducted with help of several important Ayurvedic and Modern textbooks, Research papers, Research Article, Journals to collect information on Karshya. The description of Karshya clearly correlates with under nutrition. Conclusion: Ayurveda can play major role in providing health to children. In Ayurveds, Balya an Bruhana Chikista for undernourished children is an interesting area in the field of Kaumarbhritya. Since we try to review of article on management of Karshya.

Keywords: Karshya, malnutrition, Ayurveda 


\section{INTRODUCTION}

Karshya is one of the common problems in children. Karshya is an Aptarpanjanya ${ }^{[1]}$ vyadhi. It is a disease in which the body get emaciated, gradually. According to Charak Karshya is described under eight despicable per so (AstauNinditiya Purush) ${ }^{[2]}$. [Food (Aahara) is one of the three sub-pillars of life as per Ayurveda. Karshya has been categorized under nutritional deficiency. The clinical presentation of Karshya is described in text in presence of Shuksha Shroni, Udar $n$ Greeva, Dhamanijala Santataha reduce muscle, Twakasathi Shisha, prominence of joint, Sthoolparva Altered function of Vayu and Agni leads to insufficient production of Rasa Dhatu. Upososhan of Rasa Dhatu takes place leading to Dhatukșhaya chronologically. Hence the patient of Karshya suffers from indigestion, malabsorption and defective metabolism. Meda and Mamsadhatukșhaya at microscopical level, ultimately express its symptoms macroscopically. These sequences are very much correlated to under nutrition. Under nutrition is a condition in which there is inadequate consumption, poor absorption or excessive loss of nutrients ${ }^{[3]}$. The term malnutrition refers to both under nutrition as well as over nutrition. Childhood under nutrition is an underlying cause as an estimated $35 \%$ of all death among under 5 and $21 \%$ of total global disability ${ }^{[4]}$. It hampers the immunity and make the child susceptible to various infections.

\section{Definition of Karshya-}

Karshya: It is under nutrition condition due to reduce food intake of baby resulting from less intake, if mother use Vata vardhak Ahar-Vihar and baby take Vata Dushit Stanya,8-9 ultimately babies become malnourished. According to Ayurvedic texts the Alpashana (reduced intake of food) and Vishamashana (false habit of intake) are two important predisposing factors which play a major role in pathogenesis of karshya disease.

\section{Pathophysiology of Karshya-}

Etiology \& impact of malnutrition: In Ayurveda Karshya is Apatarpana Janya Vyadhi and etiological factors are described below as fallow.
Ahar janya factor ${ }^{[5]}$

Kashaya ras atisevan

Langhana (Fasting)

Promitasan(Littlediet)

Vatala ahara (food which initiate vata) Krodha (Anger Rukshaannapan (Indulgence of rough food $n$ drink)

\section{Vihar janya factors:}

Atisnanabhayas(indulgence in bath), Ati Vyayama (Excessive Exercise), Dhyana(Meditation), Nidra Nigraha(Suppression of natural urges such as sleep), Kshuda Nigraha (Suppression of natural urges such hunger), Pipasa Nigraha (Suppression of natural urges such thirst). According to Acharya Charaka over lean (Atikrushya) persons are described under eight despicable persons (Ashtau-ninditiya Purusha) along with over obese (Medasvi) person.

\section{Signs and symptoms of karshya:}

Achariya Charaka has been described the lean person has Shushka-Sphic, Udar, Greeva (Dried up buttocks, abdomen, neck), Dhamanijala Santataha (Prominent vascular network) Twagasthi Shesh, Ati krusha (Remnant of skin and bone), Sthoola parva ( Thick joints ), Vyayam Atisauhityam (The over lean does not tolerate physical exercise, over saturation), Kshutpipasamay-aushadham (dose not tolerate high in toxicity of hunger, thirst, disease, drugs ), Atishitoshna-maithunam (Too much of cold, heat and sexual intercourse). ${ }^{[6]}$

Samprapti: Karshya is the disease correlated with under nutrition. It is an Apatarpana Janya Vyadhi (disease caused due to under nourishment) where Vata Dosha (bio-humor) plays an important role in the pathogenesis,

Samprapti Ghatak: Dosa-Vata, Dushya-Rasa dhatu, Agni- Mandagni, Ama- formation of Ama due to Agnimandya, Srotas affected -Rasa vaha,Raktavaha, Medavaha, Mamsavaha, Type of Srotodusti -Sanga, Rogmarga- Abhyantarrogamarga, Vyaktasthan Sphiga, Udar, Greeva, Twak, Asthi, Vyadhiprakar Chirakari. Sadhyasadhyatwa - Kricchasa 


\section{Karshya Samprati: $:^{[7]}$}

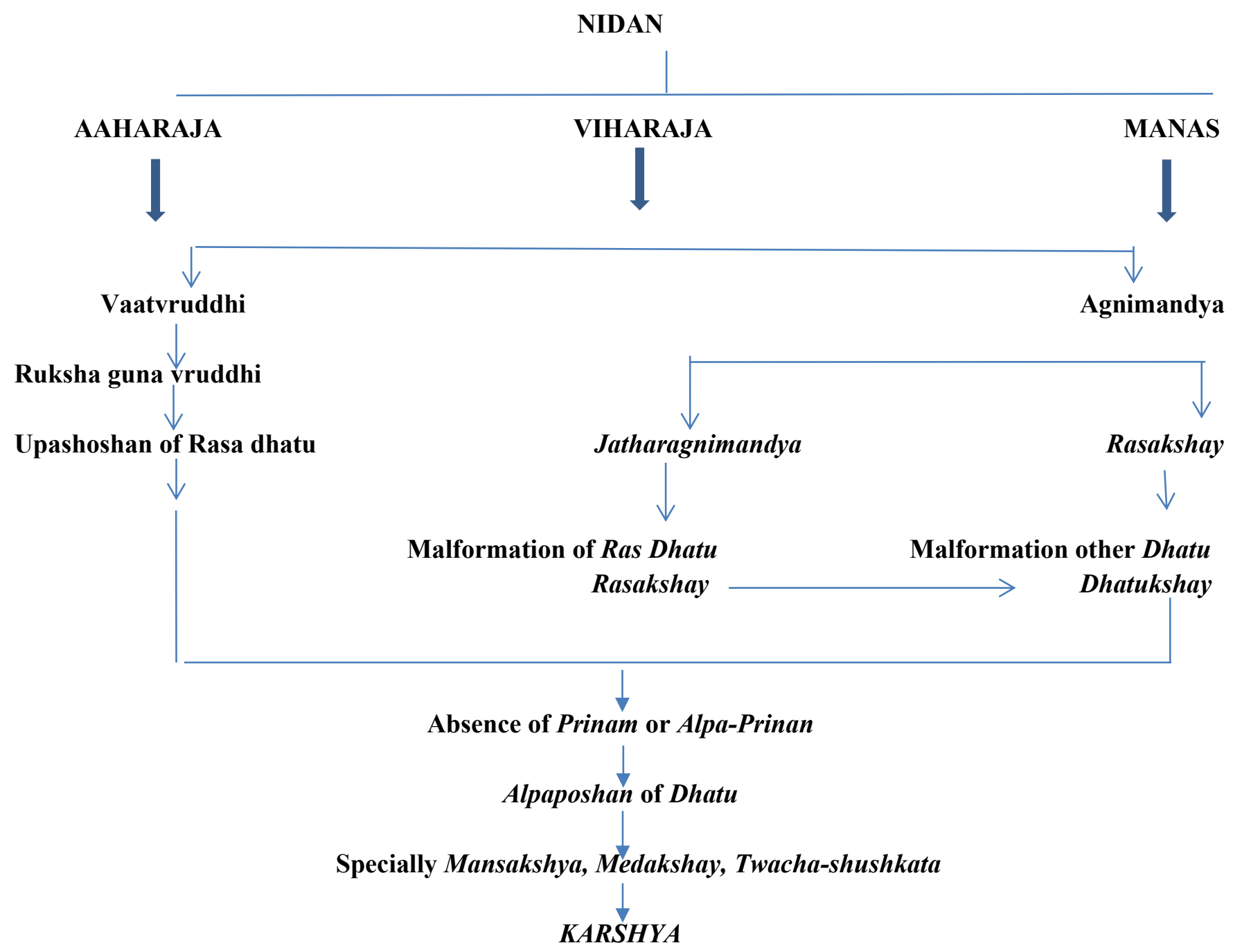

Complication of Karshya; Acharya Charka has been described many complications of Karshya they are: The lean person becomes a victim of Pleeha, Kas, Kshaya, Swas, Gulma, Arsha, Udar, Grahani. ${ }^{[8]}$

Failure to thrive (FTT) - Failure to thrive usually refers to weight below $3 \mathrm{rd}$ or 5 th centile. The degree of Failure to thrive (FTT) is usually measured by calculating weight, height and weight-for-height as percentage of the median value for based on appropriate growth chart.

Protein Energy Malnutrition (PEM: PEM is a range of pathological condition arising from in adequate proportion of protein and calories, occurring most frequent in infants and young children,
IAP classification of malnutrition: This classification is based on weight for age values. 23

Grade of malnutrition Weight-for-age of standard (\%): Normal $>80$

Grade 1, 71-80 (mild malnutrition)

Grade 2, 61-70 (moderate malnutrition)

Grade 3, 51-60 (severe malnutrition)

Grade 4, $<50$ (very severe malnutrition)

Moderate to severe malnutrition is associated with one of the classical syndromes, namely, Marasmus, Kwashiorkor, and Marasmic-Kwashiorkar. 


\section{Chikista Sutra and Management}

1. Laghu Dravya Santarpan Chikitsa that means light and nourishing diet should be administered in Karshya Rogi ${ }^{[9]}$

2. In chronic state of Karshya the refreshing therapy should be administered slowly depending upon the physical constitution, power of digestion, Doshas vitiated, nature of therapy, dose, season and time of administration.

3. Avoidance of etiological factors because this Nidana Parivarjana. ${ }^{[10]}$

4. Samshodhana (Purification therapy), Samshamana Chiikitsa(Conservative therapy), along with diet and lifestyle are helpful in preventing controlling as well as eradication of the Karshya.

5. It is an Agnimandya disorders so principles of treatment shall be on the lines of Agnidipana, Brimhana, Dhatusara vardhana.

6. Achariya Charka has been described the line of treatment of Karshya through diet management e.g. Light and nourishing diet is prescribed for the nourishment of the Karshya patients. Such diets being light serve as stimulants of digestive power and bring about nourishment due to their nutritive property as well as prevent of emaciation and nourish to the child . ${ }^{[11]}$

7. Absorption and digestion of food items mainly depend on liver function and in some case of malnutrition liver functions reduced, so in such condition liver function boosting medicine play a major role for increase appetite and absorption some examples of liver boosting herbs such

8. Brumhana therapy: In case of malnutrition Brumhana therapy may be more effectively because Karshya is an Apatarpana Janya Vyadhi and Brumhana Drayva promotes healthy growth of Dhatus, particularly Kapha (type of bio humor), Mamas (muscles) and Meda (fat) leading to proper development and enhancement of different body parts.

9. Samshodhan therapy: According to Ayurvedic texts Vata Dosha being a prime responsible factor along with Agni in the pathogenesis of Karshya disease, So Basti Karma is choice of Panchkarma procedures in malnourished children.

10. Immune therapies: Malnourished children more prone to infection due to poor immune function, most common site of infection is the skin, the alimentary tract, the respiratory tract and the urinary tract

11. Swarna Prasana: It is a type of Samskara which play a major role to modulate the immunity and improve quality of life. One pharmaco-clinical study, done on the Madhu Ghrita-Swarna-Vacha combination given to neonates showed a significant effect of humeral antibody formation and it acted on immunological system, which was evident by triggering the response of immunological system arise in the total protein and serum IgG level.

12. Rasayana therapy: Rasayana therapy also immune booster due to proper uptake, growth and improvement of essential Saptadhatus (seven vital tissues). ${ }^{[12]}$

\section{Panchakarma Therapy (Purification)}

In Karshaya (under nutrition) prominent Dosha is Vata. So Basti is the best therapy to win over the Vata Dosha. Combination of Kshira Paka and Kshira Basti therapy in Karshya is better than individual therapy.

\section{DISCUSSION}

In Charak Samhita, Sutrasthan lakshan, Nidan, Chikista of karshya is described in a view of nutritional deficiency. Sushruta has also considered Karshya as a clinical state of under nutrition. Samprati of karshya described in Sushrut Sutrasthan. Ashtang Hridya Sutrasthan Karshya has described in Kshudhavegadharan Janya Vyadhi. [13] Kashyap Samhita Karshya is included in Vataja Roga. In treatment schedule Brimhan therapy is highlighted. ${ }^{[14]}$ Karshya in Madhav Nidan is described on Roga Lakshana rather than individual Roga ${ }^{\left[{ }^{[15]} \text { Sarangadhar }\right.}$ has included Karshya in Nanatmaja Vatavyadhi ${ }^{[16]}$ In BhavPrakash Karshya has described as a separate chapter The Nidan, Lakshana, Samprapti, Chikitsa all are explained. ${ }^{[17]}$ In Yogaratnakar Karshyaroga is mentioned in the Medoroganidan. ${ }^{[18]}$ Some previous 
scientific work was carried out on topic of Karshya. They are shown below. In the year 2017 from this period Dec -Jan some a clinical study of Vidarikand churna was done, Total 28 patients were taken. It shows better results in Subjective Parameter and also increases Weight, BMI, Height, Mid Arm Circumference. 16 patients were markedly Improved and12 shows improvement. ${ }^{[19]}$ In the year 2018 in period Jan -Feb A clinical study of kshirtaila basti was done Total 20 patient was taken I show $40 \%$ show moderate improvement and $30 \%$ show mild improvement by onle $3 \%$ patient show mark improvement with no improvement in rest of $3 \%$ patient. ${ }^{[20]}$ In the year Mar - Apr 2016 A clinical study of Ashwagandha Ghruta was done Total 20 patient was taken In Objective parameters, weight gain and BMI were found to be statistically significant. The subjective parameters in study group like Nidra, Kshuda and measures of morbidity are statistically significant. ${ }^{[21]}$ In the year 2020 A clinical study of Goghruta was done in June-July. Total 30 patient was taken Goghruta show Balya effect on karshya patient. ${ }^{[22]}$ In the year 2018 a clinical study on Ashwagandha Ghrita Snehapana and Matra basti in karshya was done .Total 30 patient was taken, whereas Matrabasti is found very effective. ${ }^{[23]}$

\section{CONCLUSION}

Karshya is a disease caused by nutritional deficiencies in which the body gets emaciated gradually. Mainly the gluteal region, abdomen and neck show gross bulk muscle loss and subcutaneous fat depletion. This condition is very much similar with under nutrition.

\section{REFERENCES}

1. Agnivesh Charak Samhita Sutrasthan -23/27 with Ayurveda-Edited with Vaidya manorama Hindi Commentary-, Chaukhmba Sanskrit Prakashan, Varanasi (India) Reprint Edition 2011 Page No 320

2. Agnivesh Charak Samhita Sutrasthan $-21 / 3$ with Ayurveda-Dipika commentary by Chakrapanidatta and edited by Vaidya Yadavji -Trikamji Acharya, Chaukhmba Sanskrit Prakashan, Varanasi (India) Reprint Edition1984Page no 117
3. Ghai OP, Paul V.K., Bagga Arvind. Editors. Essential Pediatrics,New Delhi: CBS Publishers \& Distributors private Limited; 2013, Edition.8thReprint2016 Chapter 6 , page number 95 .

4. Ghai OP, Paul V.K., Bagga Arvind. Editors. Essential Pediatrics, New Delhi: CBS Publishers \&Distributors private Limited; 2013, Edition.8thReprint2016 Chapter 6 , page number 95 .

5. Agnivesh Charak Samhita Sutrasthan -21/12 with Ayurveda-Dipika commentary by Chakrapanidatta and edited by Vaidya Yadavji -Trikamji Acharya ,Chaukhmba Sanskrit Prakashan, Varanasi (India) Reprint Edition1984Page no 401

6. Agnivesh Charak Samhita Sutrasthan -21/15 with Ayurveda-Dipika commentary by Chakrapanidatta and edited by Vaidya Yadavji -Trikamji Acharya ,Chaukhmba Sanskrit Prakashan, Varanasi (India) Reprint Edition1984Page no402

7. Kaviraja Ambika dutta Shastri, Sushrut Samhita Sutrasthan 15 /32 Chaukhamba Orientalia Varanasi Page no 73.

8. Bhavprakash Publisher Chaukhmba Sanskrit Bhavan Varanasi Edition 2013 Karshyadhikar Chikista prakaran40

9. Agnivesh charak Samhita Sutrasthan -21/20 with Ayurveda-Dipika commentary by Chakrapanidatta and edited by Vaidya Yadavji -Trikamji Acharya, Chaukhmba Sanskrit Prakashan, Varanasi (India) Reprint Edition1984Page no 404

10. Sushruta Samhita of Maharshi Sushruta, edited with Ayurveda Tatva Sandipika by Kaviraja Ambikadatta Shastri Part - I Chaukhambha Sanskrita Samsthana, Charu printers, Reprint edition year 2005 Sutra sthana 15/36 page no 63 .

11. Agnivesh Charak Samhita Sutrasthan -21/30 with Ayurveda-Dipika commentary by Chakrapanidatta and edited by Vaidya Yadavji -Trikamji Acharya, Chaukhmba Sanskrit Prakashan, Varanasi (India) Reprint Edition1984Page no 405

12. Agnivesh Charak Samhita Sutrasthan -21/33 with Ayurveda-Dipika commentary by Chakrapanidatta and edited by Vaidya Yadavji -Trikamji Acharya, Chaukhmba Sanskrit Prakashan, Varanasi (India) Reprint Edition1984Page no 405

13. Srimad Vagbhata- Ashtanga Hridayam, Nirmala Hindi Commentary Along with Special Deliberation etc. by Dr, Bramhan and Tripathi; Chaukhamba Sanskrit Pratishthan, Delhi. Sutrastan 4/11, pg. no.56 
14. Vruddhajivakiya Tantra Kashyap Samhita Revised By VATSYA with Sanskrit introduction Chakhamba Sanskrit Sansthan, Varanasi, Rog Adhyay chapt-27 page no 42.

15. Madhav Nidan Part II revised and Edited by Prof. Yudunandana Upadhaya Chaukhamba Prakashan Varanasi Chapt 68 Page No-452

16. Sharangadhar Samhita Vol 1, Sri Radhakrushana Parashar, Ayurveda Acharaya, Baidhyanath Ayurveda Bhavan Limited, Edition 4th, 1994, page number 123,124

17. Bhavprakash Publisher Chaukhmba Sanskrit Bhavan Varanasi Edition 2013 Karshyadhikar Chikista prakaran 40/3.

18. Yogranatkar Edited and Translated By Dr.Rameshwar Pandey Chaukhamba Vishvabharati Varanasi

19. Vol 5, Issue 2, 2017Dr. Bansode Sheetal World Journal of Pharmaceutical Research Article ISSN 2277-7105 Article revised on $7 \mathrm{dec} 2016$

20. Journal of Ayurveda and integrated medical science JanFeb 2018 Issue -1 ISSN:2456-3110

21. WWW.ijrap.net Research Article Patil Amrut Ramgounda /Res.Ayurveda Pharm.March-April 2016

22. International Journal of Advanced Research Dr. Swati Khandale ISSN NO- 2320-5407

23. Journal of Ayurveda and integrated medical science Dr. Vijaylaxmi B.Patil Nov dec 2018 ISSN: 2456-3110.

\section{Source of Support: Nil \\ Conflict of Interest: None Declared}

How to cite this URL: Warole Ruchita Bhimrao et al: Ayurveda Perspective Of Undernutrition In Children \& Its Management: A Systemic Review. International Ayurvedic Medical Journal \{online\} 2021 \{cited March, 2021\} Available from: http://www.iamj.in/posts/images/upload/589_594.pdf 